\title{
THE IMPLEMENTATION OF THEORETICAL ASSUMPTIONS IN SERBIAN LANGUAGE TEACHING PRACTICE
}

\author{
UDC 371.3:811.163.41
}

\author{
Marina S. Janjić, Aleksandar M. Novaković \\ University of Niš, Faculty of Philosophy, Serbian Department, Niš, Serbia
}

\begin{abstract}
The subject of this paper is the implementation of theoretical knowledge in the processes of teaching practice realization, while the focus of the research is on identifying the causes of students' most common mistakes during the realization of the course Professional (methodological) practice of Serbian language teaching at philological faculties. By analyzing the records and material (student portfolios for the realization of the teaching practice) from the exam classes provided by students of the Serbian language and literature from the Faculty of Philosophy in Niš during four academic years (from 2015/16 to 2018/19), we found and analyzed characteristic beginner mistakes, and classified them into six categories: methodological mistakes in class realization, a lack of compliance with teaching principles, a lack of required class structure, unskilled application of teaching forms and methods, unskilled application of teaching aids (and technical aids) and mistakes in behavior and communication. The results obtained point to the complexity of teaching theory (developmental and pedagogical psychology and didactics), which needs to be linked to academic disciplines (linguistics, science of literature and the literary art itself) during the methodological formation of Serbian language and literature classes.
\end{abstract}

Key words: teaching theory, methodological practice, successful class, Serbian language, most common mistakes, reflexive practice

\section{APPROACHING THE PROBLEM}

It is a fact that, despite the acquired theoretical knowledge on the basics of the Serbian language and literature teaching methodology, students often have doubts about how to organize and present a class. This is especially evident in Serbian language and literature classes where the existence of three teaching areas requires additional skills. Practice has shown that although students master the course material from pedagogy,

Submitted March 5, 2020; Accepted May 19, 2020

Corresponding author: Marina Janjić

University of Niš, Faculty of Philosophy

E-mail: marina.janjic@filfak.ni.ac.rs 
psychology and methodology classes well, the complexity ${ }^{1}$ and nature of the subject itself influence the occurrence of beginner mistakes in the realization of language and literature classes in elementary or high schools. The subject of this research paper is the implementation of theoretical knowledge in the processes of practical realization of the teaching practice of the Serbian language. The problem of research is focused on diagnosing the students' most common mistakes during the realization of the course Professional (methodological) practice of Serbian language and literature teaching.

The aim of the study is to analyze the materials with comments and critical attitudes towards the observed Serbian language exam classes in order to diagnose the most common mistakes which students make during the organization and presentation of classes. Based on this, we will provide specific advice on how it is possible to prevent the occurrence of mistakes, that is, offer the best (and the easiest) solution for their eradication.

We started with the hypothesis that Serbian language students make the same mistakes when they take Serbian language exam classes, i.e. that the same beginner mistakes are repeated from generation to generation.

Given that the writing of this paper involved conducting theoretical and descriptive research, the sample consisted of records from the field of Serbian language study during a period of four academic years, namely from 2015/16 to 2018/19. The documentation was based on the analysis and concrete observations of 198 Serbian language exam classes passed in the classrooms of the Faculty of Philosophy in Niš by four generations of fourth-year students of Serbian language and literature at the Faculty of Philosophy, the University of Niš.

During the research, the theoretical analysis method was used, i.e. a descriptive method combined with the qualitative processing of data and the results obtained. The technique we used during the realization of the research was content analysis.

\section{THE RESULTS AND DISCUSSION}

\subsection{The most common mistakes made by student-teachers while presenting Serbian language exam classes}

The majority of beginner mistakes occur on the borderline between theory and practice, where the student-teacher represents the last link in that relationship. In fact, no mistake exists just by itself because it leads to new ones. By analyzing the records of language classes presented, it can be noticed that all beginner mistakes can be classified as follows: methodological mistakes in class realization, a lack of compliance with the teaching principles, a lack of required class structure, unskilled application of teaching forms and methods, unskilled application of teaching aids (and technical aids), and inappropriate behavior towards and communication with the learners.

\footnotetext{
${ }^{1}$ The course Serbian Language and Literature implies the teaching of two subjects within one course. It is known that in the majority of European countries the school system requires a separate course for the mother tongue and a separate course for literature since they are related but still separate scientific fields (linguistics on the one hand and literature and the science of literature on the other). In Serbia, these two courses were united in the years after World War II.
} 


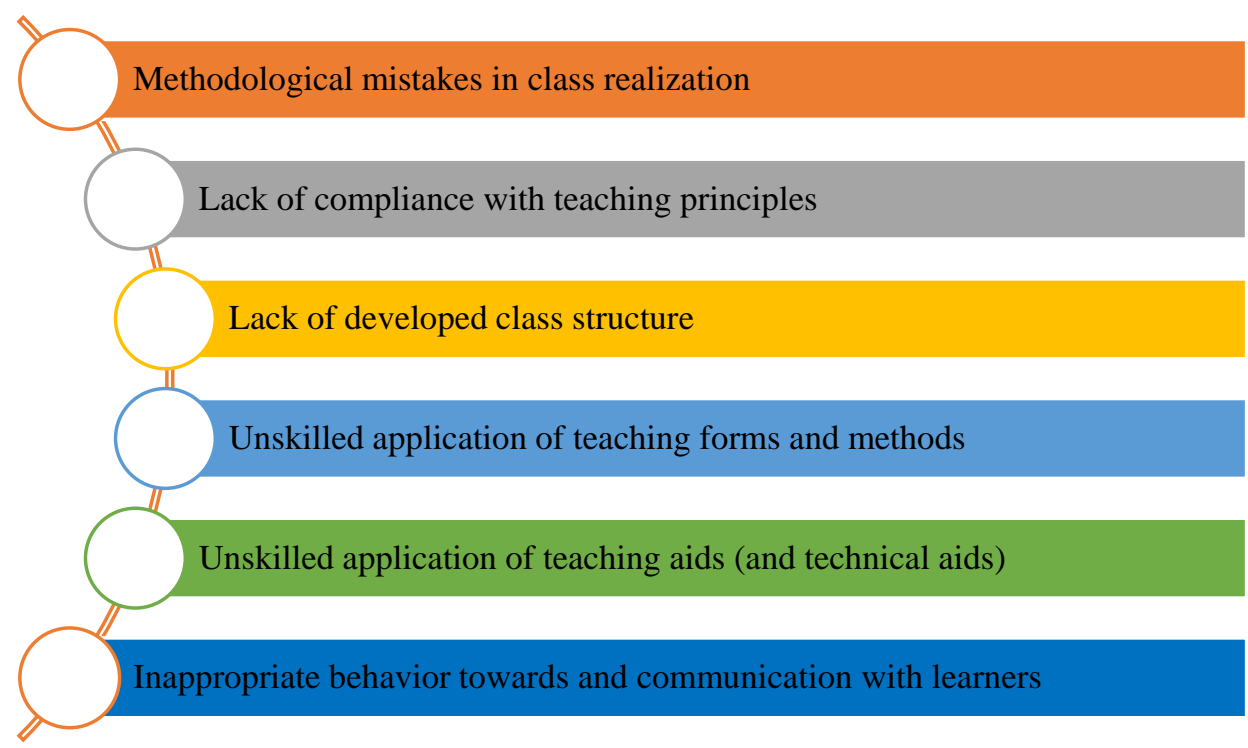

Fig. 1 A list of the most common mistakes made by student-teachers in Serbian language practical classes

\subsubsection{Methodological mistakes in class realization}

Since presenting an exam class implies a variety of activities (from reading the literature to writing the class preparation), any deviation from the planned course of the class created in the student-teachers a feeling of unease and anxiety, i.e. methodological anxiety. In practice, this is manifested in the following two ways: a) the student-teacher completely loses control of the class, and has the desire to finish the class as soon as possible, and b) the student-teacher shows resentment, with a clear desire to remove the "disobedient" learners from the class. According to the Rulebook on the Manner of Regulation of Student Absences, it is explicitly stressed, in words (and images), that the teacher is not allowed to remove the learner from the class (RMRSA 2017, 1), which practically means that the student-teachers must adjust their actions to the demands (and responses) of the learners, as well as demonstrate resourcefulness. We noticed another extreme as well, which is very common in student-teachers' actions during the practical class. Namely, the student-teacher often falls into the trap of their own need to be friendly to the learners, adjusting his/her own behavior to the learners' behavior, which leads to the emergence of an uncontrolled working environment and the impossibility to cooperate. What occurs is a lack of discipline, time is lost, as is energy, but also the focus shifts from important teaching materials. In such situations, an important role is placed on the advice received from the mentor, professors and teaching assistants, who know the discipline models aimed at learners' behavior control (Tadić 2014, 142): "Some advice that the studentteachers received from university professors was also helpful to the mentors, as well as the general philosophy of teaching that the university professors seek to impart to their students" (Petrović 2009, 64). However, it may happen that the student-teacher does not accept such advice. As a consequence of this type of behavior, a number of new mistakes emerge, such as the disregard of the principle of appropriateness, i.e. the discontinuation of the learners' thinking process. 
In connection with the foregoing, the student-teacher seeks to show to the class assessors that he/she skillfully manages the class. However, some actions say to the contrary. One of the most common mistakes in teaching is holding the lesson plan in one's hands as a reminder - the sequence of questions that the learners need to be asked. Observations of such classes show that, conditionally, the student-teacher admits to the class that he/she has mistakenly forgotten what he/she needs to do.

As a common beginner mistake, there is an absence of eye contact with the learners. Specifically, the teacher is expected to maintain eye contact with all learners, monitoring their reactions and behavior in order to complete the class successfully (Barati 2015, 222). However, the presence of the class assessors, the existence of stage fright ${ }^{2}$, and learning the class scripts by heart, lead to the situation in which the student-teacher, while presenting the class, focuses his/her gaze only on one classroom row, disregarding the others. Closely related to this mistake is also focusing on a smaller number (or just one) of learners during class communication, usually the ones who participate in the class. Seeking to get a grade as high as possible and present, to his/her understanding, a good class, the student-teacher is inclined to ask just the learner who regularly volunteers to answer, creating an apparent sense of learner activity. The student-teacher forgets that he/she must also 'activate' those learners who do not actively participate in the class (Abdullah et al. 2012, 520) in order to be able to snap them out of lethargy and engage them to share their thoughts. Eye contact is, in addition, very important when conveying important information. Unfortunately, in terms of quantity, the analysis of the records from exam classes shows that talking without keeping eye contact with the learners occupies the top position, and that happens in two cases: when writing on the blackboard, and when entering the aisles. In order to prevent these mistakes, the student-teacher must know that he/she must not talk with his/her face turned to the blackboard, nor can he/she enter the aisles because, in that case, a part of the learners will not understand what the teacher is talking about (so-called "unintelligible speech"). Aside from that, what often occurs as an unconscious reaction of the student-teacher is sitting at the teacher's desk, because of which the aforementioned eye contact with the learners is obstructed. During the interpretation of the teaching material during class, the teacher is obliged to stand in front of the learners in the front part of the classroom - in front of the blackboard (except in the case of group work when he/she visits them and checks the results of their work).

In order to create a positive and working atmosphere in the classroom, while taking the exam class, the student-teacher must with his/her energy and dedication serve as a motivation to the learners. However, sometimes student-teachers, because of a large number of obligations as part of their university lectures, understand the exam classes as an obligation and approach them with no energy. That kind of attitude also brings about the appearance of a "failed class" in which the expected outcomes are not achieved. Practice has shown that, in such classes, the teacher is almost invisible and inaudible, given that, in the majority of cases, he/she speaks silently ${ }^{3}$ and lifelessly, leaving room for the learners to overpower him/her. That is why it is expected from the teacher to be the leader in the class, to initiate work and creative energy in the true sense of that word.

\footnotetext{
${ }^{2}$ Stage fright represents a very important factor that influences student-teachers' success in a particular class. The amount of its impact on the student-teachers' achievement can be seen in the fact that $75 \%$ of classes can be divided into two parts, where the second part of the class is always more successful. Namely, as the studentteachers usually say, stage fright is mostly present in the first five minutes of the class.

${ }^{3}$ With voice not adjusted to the circumstances he/she is in.
} 


\subsubsection{Lack of compliance with teaching principles}

The second group of characteristic mistakes is related to non-compliance with the teaching principles, above all, with the principle of conscious activity in teaching, which is the basis of contemporary teaching. Because they want to introduce the learners to all the characteristics of the teaching unit they are studying in class, student-teachers often resort to the dysfunctional use of the monologue method, which entails the passivity of learners in the class. Similar effects are caused by the use of presentations which do not have the necessary didactic-methodological design, which is why learners are put in the position of listeners instead of equal participants in the teaching process.

It is often the case that the principle of the appropriateness of the material for learners is not followed either. "The essential requirement of the principle of appropriateness is that the learners' capabilities should not be either overestimated nor underestimated, but that the material and their age need to be matched as much as possible" (Ilic 2006, 39). Failure to comply with this principle occurs in two ways: 1) as a disregard of the age capabilities of the learners and their interests, and 2) by not adjusting the volume of content with the cognitive apparatus of the learners. The Disregard for the learners' age abilities occurs when giving (too) easy or (too) difficult work orders and tasks: How many cases are there in the Serbian language? When renewing the knowledge of cases, that is, Interpret the following formula: Apposition = renaming a noun, in the fifth grade of elementary school. Also, student-teachers sometimes pick inadequate language items for grammatical analysis in class, guided by the principle of their own choice rather than the principle of the interests of learners of a certain age, as should be the case. The second aspect is a consequence of faculty teaching and reading more extensive literature, which occurs when student-teachers go beyond the structure and requirements prescribed by the curriculum: explaining the third palatalization from the point of view of diachrony when teaching palatalization or sibilarization. This form of error entails a reduction in comprehensibility and a failure to comply with the principle of economy. The disregard of the principle of economy by the student-teachers is a consequence of an unskilled realization of the class. It most commonly occurs in the form of overemphasis, which means that the scope of the study material is not adjusted to the age and abilities of the learners, as well as due to writing in block letters on the blackboard ${ }^{4}$, which requires extra time.

The exactness as a specific characteristic of language requires the use of relevant literature in the field of language science. Even though student-teachers write a preparation before presenting classes, and their professors check it, the real conditions of the class (the teaching situation, learners' questions, etc.), due to the appearance of anxiety or some other reasons, influence the occurrence of material errors. A material error implies an error which impairs the scientific basis of student-teachers' work (the disregard of the principle of science). For example, in a grammar lesson, a studentteacher claimed that in the sentence: Не храни се прасе уочи Божића [NB: a Serbian phrase which means "do not wait until the last minute to do something"], the underlined word was an adverb. Very often, student-teachers mistake the possessive adjective for the possessive pronoun and mistakes with grammatical cases happen during communication in the exam class. Such mistakes lead to the incorrect adoption of the material and later to the violation of the accuracy of the standard Serbian language in everyday use.

\footnotetext{
${ }^{4}$ Writing in block letters is recommended only when it is necessary to emphasize the importance of a particular part of the material studied.
} 
Being systematic in teaching plays a key role in achieving its goals, i.e. in achieving success in the learning process. The quality of a Serbian language class depends on the way in which the student-teachers organize the class, that is, on the degree of adherence to the rule "from what is more to what is less understandable", "from the familiar to the unfamiliar" (Ilic 2006). A Failure to comply with this principle rarely comes to light because of its very nature. It is logical, for example, when the class deals with sound changes, to work first with the classification of sounds in the Serbian language, and then with every phenomenon individually, or, when the types of word formation in the Serbian language are explained, to explain first the term word family and its function, and then to talk about different models.

\subsubsection{Underdeveloped class structure}

A mistake which is very common in the student-teachers' work is the lack of a necessary lesson structure, which is why, as a consequence, the discontinuation of the thinking process occurs. In their book Nastavno dizajniranje časova srpskog jezika [Lesson Design of Serbian Language Classes], Janjić and Novaković (2015) highlight the obligatory stages through which a language class must pass, where a three-part structure of the lesson is advocated, which encompasses a higher number of steps: motivating learners, announcing the teaching unit and highlighting the lesson goal (introductory part); using the language teaching methodology template, analysis of examples, derivation of the characteristics of the phenomenon studied, the existence of the phase of knowledge insurance and synthesis, i.e. generalization (operative part of the lesson); a creative application of knowledge and homework assigned within the evaluative part (final part of the lesson). However, practice has indicated that student-teachers (sporadically) make mistakes in all lesson stages. Thus, a non-functional introductory or final part of the class occurs. For example, using the associations game, as a form of playful teaching, does not in any way mean that the introductory part of the class will, by default, be functional: it will be such if, while working on palatalization, the associations game is used for the repetition of the material on the division of consonants, and it will not be such if the associations game is only used for fun. In addition, student-teachers often, after the motivation and the announcement of a new teaching unit, revise the part of the study material which is necessary for the adoption of a new one. This disrupts the thought process of the learners, because everything that needs repetition should be revised in the introductory part of the class. Therefore, after the announcement of the teaching unit, the material learned previously should not be repeated, except in special cases. Also, as an unavoidable phase during the announcement of the new teaching unit, the lesson goals are highlighted, which implies giving the answer to the question: Why is today's teaching unit important to the learners? However, the most common mistake is leaving out the synthesis, which implies the definition of the teaching unit taught in class.

Closely related to not complying with the lesson structure is also the lack of compliance with the time structure of the lesson. Inexperience in teaching causes two situations: the premature termination of the class or leaving out the final part of the class (due to a lack of time). The first case occurs if the student-teacher (together with the learners) moves too fast through the content or does not adjust the scale of the content to the time available, and the second case occurs due to the extension of the introductory or operative part of the class (not complying with the principle of economy). In order avoid such a scenario, the student-teacher should have a good understanding of the instructions for curriculum implementation, that is, 
the student-teacher should use the textbooks as a framework (in the choice of content and the depth of its interpretation) through which he/she should navigate.

\subsubsection{Unskilled application of teaching forms and methods}

Teaching implies interaction between teachers and learners, where communication goes two ways. It is interesting that during the expected flow of conversation in a Serbian language class, the teacher's question - learner's answer model tends to appear. However, the content, and also the teacher's method of choice, can often be a trigger for a large number of learner questions, which is actually desirable in contemporary teaching. However, the nature of the exam class and the specific circumstances of its realization lead to student-teachers' disregarding learners' questions, considering them less important (and not functional) for the continuation of the class, even though Vilotijevic (2008) states that learner questions represent the essence of heuristic teaching. Thus, it may happen that during the use of the language teaching methodology template the learner asks the studentteacher where the excerpt was taken from, and that the student-teacher does not respond, trying to direct his/her class towards the previously-decided goal. It also happens that the student-teacher does not pay enough attention to the learners' answers, so as to, for example, disregard the existence of the difference between the words rečica (a small river) and rečca (a type of word), which later leads to the misuse of the term by the learners. In addition, related to the achievement of interaction, the student-teachers often, unknowingly, resort to the use of monotonous and banal questions.

When it comes to the use of terminology, the most common mistake that the studentteacher makes during the exam class is the use of terminology not appropriate for the learners' age (for example, renaming of a noun when marking the apposition), i.e. the terminology which indicates methodological steps in the lesson (And now we will use mnemonics.). It is interesting that the student-teachers often use the term "typical example" to label the most frequent form of a particular language item. However, the use of typical examples also brings about learners' thought inertia, because it is easier for the learners to learn one example by heart than to search for new examples.

As they have prepared, and carry with them to class, a detailed description of the flow of conversation, the student-teachers aim to get the responses that they had assumed the learners would provide. Because of this, they often do not let the learners express their opinion regarding the material being discussed, seeking exactly the kind of opinion that matches the imaginary one (from their lesson plans). As a consequence of such a method, the demotivation of learners for further class work occurs, as well as the overuse of the monologue method. However, it should be noted here that, even though the monologue method is usually seen as a traditional one, student-teachers resort to it in order to achieve the efficiency of class and respect the planned time structure of the class. This happens especially in the synthetic phase of work, when the studied linguistic phenomenon needs to be defined. Instead of the learners being the ones to define the linguistic item, studentteachers, in order to save time, give their own definition unfamiliar to the learners.

In contemporary methodological manuals, group work is highlighted as the most functional and the most effective (Janjić and Novaković 2015, 27). However, in order to take advantage of group work, certain experience is necessary, which cannot be expected from the student-teachers, and this leads to mistakes. Mistakes happen for at least two reasons: firstly, they happen in situations when the learners have never before been organized into groups, so they consider this form of work to be play, and secondly, which 
often happens, the student-teachers cannot activate all the groups' members equally, due to the lack of authority.

\subsubsection{Unskilled use of teaching and technical aids}

Unskilled application of teaching aids and technical aids implies their non-functional use in teaching. The application of information and communications technology can have a positive or negative impact on teaching achievement. When it comes to the negative impacts, two cases should be pointed out: excessive use of computers and inappropriate use of computers. The excessive use of computers implies a frequent use of the computer as a blackboard replacement. Their use, usually via a PowerPoint presentation, directly influences a reduced use of the blackboard, which the learners see as an important source of information in Serbian language classes. Using presentations reduces the amount of information which the learners write down, so they do not have examples, rules and definitions of the studied language phenomenon in their notebooks. On the other hand, given that a computer (with a projector) should be used to achieve clarity, the lack of projectors in schools forces studentteachers to put their computers (laptops) on the desk (or on a raised chair). However, such an act is not only useless, but also harmful: not all learners in the class can see the monitor and understand what is being presented on it. Such situations suggest that computers are not allpowerful and that the fact that they are used in class in no way guarantees that the class will be successful. In other words, computers can do as much harm as good. Milutinović (2009, 177-178) writes that there is a need for teachers to learn about new technologies but that they also have to adjust "their current use of information technologies in the classrooms (i.e. knowledge on how to use a projector, electronic board or the text of a book) to integrate these new practices into the existing knowledge of the presented content, pedagogical knowledge, and pedagogical knowledge of the content in practice".

The use of computers and projectors in teaching results in a reduced use of the blackboard, which is also a characteristic student mistake during teaching. Thus, for example, during the processing of a teaching unit on word formation, besides the title, a greater number of examples (taken from the language teaching methodology template) should be written on the blackboard. However, a list of examples related to word formation does not mean anything if the structure of the given word is not written on the blackboard, according to the model: prefix + root + infix + suffix, which the student-teacher usually forgets to do or does it orally. In addition, using abbreviations with foreign learners, as well as excessive colorfulness due to the use of multicolored markers, can result in the learners' disorientation due to the "abundance of data". Namely, the proper use of the blackboard implies finding a balance between necessary and sufficient data, which the learner will copy, in order to have the material to work on (and study) at home, respecting the principle of consistency. This is especially important in elementary school education.

\subsubsection{Inappropriate behavior towards and communication with learners}

One of the most respected professions is that of a teacher, which carries with it responsibility and respect for ethical and moral standards (Župljanin 2013, 163). However, aside from the ethics and morals, the teacher is a role model for the learners also in terms of the way he/she dresses, not only in school but also outside of it. Even though it rarely happens, it is important to advise the student-teachers to respect the dress-code appropriate for their profession. 
On the other hand, a Serbian language teacher is expected to respect the orthographic and orthoepic norms, but "more than that, the awareness of the fact that they, as future educators (teachers), are entering the ranks of very special users of language" (Čutura et al. 2009, 339). However, the anxiety which the student-teachers experience during their first classes in the role of teachers influences the use of filler words and hypercorrected forms:

"Often, this anxiety stems from the belief that its use is not in accordance with the language standard or style which is expected from the speaker. The standard language form is a codified form that is used in public discourse, whereby it represents a prestigious form of linguistic variety. The variables that differentiate the standard form from the nonstandard form are related primarily to the phonetic realization, vocabulary, syntax and many other linguistic factors" (Novaković 2016, 338).

\section{CONCLUSION}

The analysis of the records of exam classes of the students of Serbian language and literature of the Faculty of Philosophy in Niš has shown that all beginner mistakes can be classified as follows: methodological mistakes in class realization, lack of compliance with the teaching principles, lack of a developed class structure, unskilled application of teaching forms and methods, unskilled application of teaching aids (and technical aids) and inappropriate behavior towards and communication with the learners.

Mistakes in methodological class realization suggest the existence of anxiety, a lack of discipline and energy, or a lack of visual contact with the learners, due to talking with one's head turned away from the learners and sitting in the teacher's chair. Noncompliance with the teaching principles of appropriateness, science and efficiency is classified into one of the most common student-teachers' mistakes in exam classes, which is frequently the consequence of the lack of the required (time) structure of the class. Unskilled application of teaching forms and methods is most evident in the use of the monologue and dialogue method, because of which student-teachers often disregard the learners' questions and answers, ask uniform and banal questions and, by doing so, limit the learners' activity. In a quantitative sense, the biggest share of student-teachers' mistakes are related to the unskilled application of teaching aids and technical aids, which is manifested through the overuse and misuse of computers, that is, the lack of use of the blackboard. The use of filler words and hypercorrected forms appears as a characteristic mistake in addressing the learners.

Acknowledgement: The paper was written as a part of an internal project of the Faculty of Philosophy in Niš Srpski jezik nekad i sad: lingvistička istraživanja [Serbian Language Then and Now: Linguistic Research] headed by Prof. Marina Janjić, PhD (decision number: 360/1-16-10-01).

\section{RESOURCES}

ZOSOV 2017: Zakon o osnovama sistema obrazovanja i vaspitanja (2017). Službeni glasnik RS 88/2017. Beograd: Službeni glasnik.

PONRIU 2017: Pravilnik o načinu regulisanja izostanaka učenika (2017). Beograd: OŠ „Zmaj Jova Jovanović”. POSP 2016: Pravilnik o stručnoj praksi koju studenti Filozofskog fakulteta u Nišu obavljaju u obrazovnovaspitnim ustanovama (2016). Niš: Filozofski fakultet. 


\section{REFERENCES}

Abdullah, Y. M., Bakar, A. R. N., Mahbob, H. M. 2012. "Student's participation in classroom: What motivates them to speak up?". Social and Behavioral Sciences 51 (2012): 516-522.

Barati, L. 2015. "The Impact of Eye-contact between Teacher and Student on L2 Learning". Journal of Applied Linguistics and Language Research, Vol. 2, Issue 7 (2015): 222-227.

Čutura, I., Maksimović, J., Janjić, M. 2009. "Test osnovne pismenosti u selekciji studenata - budućih učitelja". Unapređenje obrazovanja učitelja i nastavnika, 8/1: 337-348.

Ilić, P. (2006). Srpski jezik u teoriji i praksi. Novi Sad: Zmaj.

Janjić, M. 2017. Metodički horizonti - odabrana poglavlja metodike nastave srpskog jezika $i$ književnosti. Beograd: NM libris.

Janjić, M., Maksimović, J., Đigić, G., Božić S. 2014. Praktikum za realizaciju profesionalne nastavne prakse sa studentskim portfoliom, Niš: Filozofski fakultet.

Janjić, M., Novaković, A. 2015. Nastavno dizajniranje časova srpskog jezika. Niš: Filozofski fakultet.

Milutinović, V. 2009. "Faktori upotrebe IKT u obrazovanju: mentori i budući učitelji". Unapređenje obrazovanja učitelja i nastavnika, 8/1 (2009): 175-188.

Novaković, A. 2016. Hiperkorekcija u govoru učenika i studenata na području prizrensko-timočkog dijalekta. Književnost i jezik, 63(3-4): 333-350.

Novaković, A. 2018. "Refleksivni model metodičke prakse na Filozofskom fakultetu u Nišu". Metodički vidici 8: $11-30$.

Petrović, D. 2009. "Tradicionalni i savremeni pogled na mentorstvo u sferi obrazovanja budućih nastavnika". Unapređenje obrazovanja učitelja i nastavnika, 8/1: 57-68.

Požar, X. 2016. "Kompetencije nastavnika u savremenom školstvu”. Sinteze 10: 23-34.

Schön, D. 1987. Education the reflective practitioner: Toward a new design for teaching and learning in the professions. San Francisco, Oxford: Jossey-Bass.

Tadić, A. 2014. Savremeni modeli i strategije uspostavljanja i održavanja razredne discipline (unpublished $\mathrm{PhD}$ thesis). Beograd: Filozofski fakultet.

Vilotijević, M., Vilotijević, N. 2008. Heuristička nastava. Vranje: Učiteljski fakultet.

Župljanin, M. 2013. "Nastavnik kao uzor u vaspitanju učenika”. Univerzitetska misao 12/2 (2013): $162-174$.

\section{IMPLEMENTIRANJE TEORIJSKIH POSTAVKI UNUTAR NASTAVNE PRAKSE SRPSKOG JEZIKA}

Predmet ovoga rada jeste implementacija teoretskog znanja u tokove realizacije nastavne prakse, dok je problem istraživanja fokusiran na identifikovanje uzroka najčešćih grešaka studenata u okviru realizacije predmeta Stručna (metodička) praksa nastave srpskog jezika na filološkim fakultetima. Analizom evidencionog materijala (studentskih portfolija za realizaciju nastavne prakse) o održanim ispitnim časovima studenata Srbistike Filozofskog fakulteta u Nišu tokom četiri akademske godine (od 2015/16. do 2018/19), autori pronalaze i analiziraju karakteristične „početničke” greške, klasifikujući ih $u$ šest kategorija: greške u metodičkom vođenju časa, nepoštovanje nastavnih principa, nepostojanje potrebne strukture časa, nevešta primena oblika i metoda nastavnog rada, nevešta primena nastavnih sredstava (i tehničkih pomagala) i greške u ponašanju i ophođenju. Kako do sada ne postoji referat koji se bavi sličnom temom u oblasti lingvometodike srpskog jezika, ovo istraživanje može biti dragocen materijal koji bi pružio instrukcije studentima o čemu bi trebalo da vode računa prilikom organizacije $i$ polaganja ispitnih ili državnih stručnih časova za rad u školi. Dobijeni rezultati ukazuju na kompleksnost nastavne teorije (razvojne $i$ pedagoške psihologije $i$ didaktike) koju treba povezati sa predmetnim disciplinama (lingvistikom, nauka o književnosti i samom književnom umetnošću) prilikom metodičkog oblikovanja časova srpskog jezika i književnosti.

Ključne reči: nastavna teorija, metodička praksa, uspešan čas, srpski jezik, najčešće greške, refleksivna praksa 